\title{
Rectifying Horizontal Inequalities: Lessons from African Conflict
}

\section{David McCoy *}

\section{Abstract}

In Africa, the decade of the nineteen nineties was characterised by civil war and interstate conflict, but as the decade came to a close and a new millennium emerged many of the protracted conflicts in Africa had officially come to an end. The official resolution of conflict in Sierra Leone, the Democratic Republic of the Congo, Sudan, Liberia and Côte d'Ivoire has helped stem the rampant instability that has plagued the continent for most of its postcolonial history. With the newly established peace agreements comes an even more critical and difficult challenge of creating peaceful societies in these war-ravaged nations. In order to rebuild a nation, one must examine and acknowledge the root causes of the conflict. One of the most prevalent and underrepresented root causes of conflict in Africa and worldwide is that of horizontal inequalities. In that light, the goal of this paper is to provide

* David McCoy received his Masters of Arts from Seton Hall's John C. Whitehead School of Diplomacy and International Relations, specialising in Conflict Management and Global Health. Mr. McCoy has spent time in Africa working on rural economic development and currently works on food security issues in New York. 


\section{David McCoy}

practical solutions for the long-term resolution of conflict by addressing one of its root causes, that of horizontal inequalities. Reference will be made to solutions proven successful in past cases where conflict emerged as a result of group inequalities, namely Rwanda and Mali. The paper will take the following form: Section one will look at the current literature on conflict and demonstrate the link between horizontal inequalities and conflict. Section two will focus on the two case studies providing background to the conflict, and the action taken after violent conflict ceased. Section three will be dedicated to the lessons learned from the Malian and the Rwandan experience, including policy recommendations that should be instituted for any nation where horizontal inequalities are a major catalyst of conflict.

\section{Introduction}

As a new century dawned there was a renewed sense that the international community would be able to quell the many conflicts and threats to peace that exist around the world; however, by the autumn of 2001 that hope was drastically altered. With the events of September $11^{\text {th }}$, the overthrow of the Taliban regime in Afghanistan and the invasion of Iraq, the much heralded Millennium Development Goals and the commitment to assisting those in the most dire of circumstances fell to the wayside in the name of national security. This new national security and terrorist agenda, which has been championed by the United States (US), remains the focus of the international community almost seven years after the terrorist attacks occurred. The international attention paid to both Iraq and transnational terrorist organisations has resulted in a departure from the humanitarian and individual focused security agenda that was beginning to emerge. However, while the US and most of the rest of the world is fixated on Al-Qaeda and the Global War on Terror (GWOT), progress towards peace and stability has developed in one of the more unstable regions of the world - Sub-Saharan Africa. There are now peace agreements in Liberia, Côte d'Ivoire, Sudan, and the Democratic Republic of the Congo, and if successful, these developments will bring much needed stability and hope to millions throughout Africa. 
The problems the US is encountering in Iraq and Afghanistan and the long road ahead for the many African nations emerging from conflict illustrate the multitude of challenges that accompany nation building. In this light, one of the most pressing questions the international community must answer is: How can nations emerging from conflict create sustainable peace and stability? The answers to this question have global relevance, but the solutions are especially necessary in Africa where, since the independence movement of the 1960s, conflict has ensued with regard to every imaginable nature. The formal peace agreements emerging in many nations are the starting point of a long process, but that process's validity and success lies in solving the root causes of violent conflict. Even though the cultures, regions and people involved in these conflicts are exceedingly complex the conflicts, in and of themselves, have one similarity: they are a result of domestic horizontal inequalities. Horizontal inequalities are inequalities between groups and can be attributed to conflicts in all parts of the world - from the US race riots in the 1960's and the 2005 Paris riots to the genocides that unfolded in Rwanda and the former Yugoslavia. Consequently, if countries and regions in Africa and the rest of the world want to develop stable peaceful societies they must rectify the horizontal inequalities that are at the root of many violent conflicts.

The ability of a nation to resolve inequalities between groups is of the utmost importance in any peace process. Thankfully, the international community and nations that are embarking on this process have a history and past experience to guide future action. In order to answer the question of how African nations and regions emerging from conflict can create sustainable peace and stability, this paper will analyse the steps African nations have taken to rectify horizontal inequalities in post-conflict environments. This analysis is constructed upon two case studies, Mali and Rwanda, and will provide lessons for future peace initiatives in Africa and beyond. Furthermore, this paper will provide an in-depth analysis with a focus on successful initiatives, something often ignored in circulating literature. The goal of this paper is to provide practical solutions for the long-term resolution of conflict by addressing one of its root causes, that of horizontal inequalities. Moreover, 
it will provide solutions proven successful in past cases regarding conflicts caused by group inequalities.

\section{Horizontal Inequalities and Conflict}

In order to understand the mechanisms needed to create peace, the reasons for the development of conflict must be understood. There exists in the international community the idea that conflict resolution is necessary and possible, however, it should also be understood that conflict should not be viewed as something intrinsically negative. Victor Azarya argues that conflict is natural and cannot be prevented. Because conflict cannot be eliminated, he further argues that conflict can only be contained and moderated (Azarya 2003:3). What the international community must aim to achieve is the elimination of violent conflict, not conflict in and of itself. Once this is understood the question then revolves around conflict management and violence prevention. The most effective way to preventing violent conflict is to address the root causes of conflict. Azarya argues that a democracy is the preferred mechanism to contain conflict because it is the 'art of conflict accommodation' (Azarya 2003:4). Democracy provides room for disagreement without having to resort to violence. Mark Malloch Brown, Deputy Secretary-General of the United Nations (UN), is also a proponent of democracy promotion stating, 'It is my strong belief that democratic governance is vital not just for ensuring sustainable development, but is vital for sustaining peace within societies' (Brown 2003:142). The greatest impediment to democracy, however, is that democratic governance will only work if all parties deem it legitimate. The goal of democracy as a tool for stability must be predicated on the full involvement of all parties and groups. It must also be recognised that while the theory of democratic reconstruction is appealing, instituting it is proving to be very difficult in practice (Ottaway 2003:315).

Other authors including Vamik Volkan argue that the root causes of many protracted conflicts are the result of ethnicity. He states, that at the 'root of many conflicts are bloodlines' (Volkan 1997:20). The argument of 
ethnicity causing conflict is normally divided into two different theories: constructivism and primordialism. The former views ethnicity as a fluid social construct and the latter views ethnicity as something that one is born into and that cannot be easily altered. Violence often develops between ethnic groups when one group feels threatened or harmed by the other, usually as a result of some inequality or perception of inequality.

Still others, including Riwanto Tirtosudarmo (2006), Thomas Homer-Dixon (1999) and Robert Kaplan (1994) view population pressures as the root of many conflicts. Said Adejumobi takes the conflict argument in a different direction, citing the denial of citizenship rights as major cause of conflict. Adejumobi (2001:156) states:

It is the consciousness of the denial of citizenship rights by a people, which usually facilitates the transformation of sectarian groups, like racial and ethnic groups, from being 'groups in themselves' into 'groups for themselves.' The idea of elite mobilization of ethnic or racial ideology, which most analysts emphasize in explaining politics and conflicts in Africa, is only possible in the context of a fertile ground of citizenship exclusion.

The exclusion of people, often groups, from aspects of citizenship creates systemic exclusion, inequalities and animosities that foster group mobilisation and violent conflict.

The control and exploitation of resources, it is argued, is a major contributor to violent group mobilisation. Paul Collier and Anke Hoeffler assert that civil conflict can be articulated as a greed versus grievance dynamic where rebellions start because of the greed of leaders or because of genuine grievance of the people. However, because rebels must finance their rebellion, the control of resources becomes an impediment for peace (Collier \& Hoeffler 2001). This dichotomy of either greed or grievance is troublesome to Karen Ballentine and Heiko Nitzschke of the International Peace Academy. They state, 'conflict analysis models should avoid "resource reductionist models" in favor of comprehensive approaches' (Ballentine \& Nitzschke 2003:1). 


\section{David McCoy}

James Busumtwi-Sam also advocates a more comprehensive approach for explaining conflict. He states that there are three interrelated factors that contribute to protracted conflict: 'contests over the state and the distribution of political power, the distribution of membership in the political community and the distribution of values and resources' (Busumtwi-Sam 2002:94). Considering a multitude of inequalities when explaining conflict creates a more complete understanding of conflict and leaves us better equipped to rebuild a state.

One of the most cited sources of inequality is poverty and, as a result, an increased level of violence is attributed to high levels of poverty. Ted Robert Gurr argued that rebellions occur when a large discrepancy exists between people's legitimate and actual levels of material reward (Gurr 1970). Nicholas Sambanis (2004:202) demonstrates that a robustly inverted relationship exists between the per capita income and political violence. It should be noted that because of the need for group mobilisation, the disparity in income must occur between groups if there is to be any occurrence of violent conflict. The argument that income disparity between people and groups creates violent conflict can be included in the larger idea of the dissolution of the social contract. Tony Addison and S. Mansoob Murshed argue that conflict can be viewed as a partial or complete breakdown of the social contract (Addison \& Murshed 2001:2). ${ }^{1}$

Many scholars have theorised and articulated what they view as causes of conflict; notably, they all directly or indirectly point to the inequalities between individuals and groups. This realisation will help guide further discussion on how to reduce the impact of both vertical (between individuals) and horizontal (between groups) inequalities. A number of scholars have addressed the question of inequalities. Frances Stewart, for example, deals with the problem of horizontal inequalities in a number of papers. ${ }^{2}$ Stewart (2002:3) argues that 'unequal access to political/economic/social resources

1 The social contract can be seen as the implicit rules that govern the distribution of resources and duties in an organised society.

2 See Stewart 2000, 2002 and 2006 for a comprehensive explanation of horizontal inequalities. 
by different cultural groups can reduce individual welfare... [and] where there are such inequalities in resource access and outcomes, coinciding with cultural differences, culture can become a powerful mobilizing agent'. Stewart recognises that it is not only the underprivileged that can become violent; groups benefiting from the current system may also resort to violence if they feel their access to resources is threatened (as happened in Rwanda). The focus on group inequalities is important because in order to have a large-scale violent outbreak groups of individuals must mobilise. Moreover, the relative position of groups within society is a determinate factor in stability, not the absolute position of the individual. As Cohen (1974:94) articulates, 'when men do fight...they fight over some fundamental issues concerning the distribution and exercise of power, whether economic, political, or social'. One's cultural, linguistic, ethnic and religious differences will not create conflict unless there are extreme political or economic issues within a society. Consequently, the greater the horizontal inequalities, be they political, social, or economic, the greater the chance for violent conflict to emerge. Gudrum Østby (2005:23) adds to the idea of horizontal inequalities as a determinant of conflict by showing that 'recent studies of the inequality-conflict nexus may be wrong when concluding that inequality is unrelated'. Furthermore, Østby (2006) establishes a relationship between conflict and severe socio-economic horizontal inequalities. The prevalence of systemic and pervasive horizontal inequalities within societies has led to the destruction and underdevelopment of numerous societies; however, the issue of group inequalities continues to lack substantial attention within academia and, more importantly, within the international development agenda.

In order to foster stability and development, societies that have experienced conflict as a result of horizontal inequalities must find a way to resolve these disparities. Much of the literature on conflict revolves around theoretical approaches without advancing applicable solutions. As a way of gaining insight into how to bridge the gap between theory and application, an analysis of how post-conflict states have addressed the problem of horizontal inequalities follows. 


\section{Case Studies: Mali and Rwanda}

\section{Mali}

With a landmass of 1.24 million square kilometres (Central Intelligence Agency 2006) and a human development index of 175 (United Nations Development Programme 2006), the country of Mali is one the largest and most underdeveloped countries in Africa. From 1990 to 1996 the government of Mali was confronted with a secessionist movement instigated by a northern nomadic population called the Tuareg. Trained by Libya, the Tuareg formed the Mouvement Populaire de l'Azawad (MPLA) with the goal of gaining independence for the Azawad region in Northern Mali. The conflict 'took place in the vast desert and mountains regions of the far north of the country a region - referred to as the "Azawad" by the rebel movements - constituting two thirds of the national territory but relatively poor in natural resources' (Humphreys \& Mohamed 2007:6). The country is bisected by the Niger River with the north of the country lying in the Sahara Desert and the south lying in a more arable and temperate climate. This climatic disparity is responsible for the smaller population in the north as well as for its economic irrelevance. The roots of the Malian conflict can be seen as a combination of ethnic fighting between the black population of the south and the paler northern population coupled with northern economic grievances (Economist 1990). Moreover, the systematic neglect, discrimination and exploitation of the northern provinces added to the Tuareg grievances against the government (Lode 1997). Almost immediately after the beginning of the conflict in 1991, the government of Moussa Traoré agreed to negotiate with the northern rebels. The talks, which took place in Algeria, resulted in the Tamanrasset Accords. These Accords as well as the Traoré government, however, proved fragile. On 26 March 1991 Moussa Traoré was overthrown. The new transitional government worked quickly to foster acceptance of the Tamanrasset Accords, but did not achieve any substantial success. Because the Accords were unpopular with the army, the rebels and the citizenry, and suffered from imprecise construction, they were increasingly becoming irrelevant (Humphreys \& Mohamed 2007:23-24). The 
installation of a new government instilled the population and the belligerents with a renewed sense that peace could be legitimately achieved. 'The [failed] Tamanrasset Accords of 6 January 1991 provided a starting point for the dialogue that would eventually lead to a settlement' (Storholt 2001:334). On 11 April 1992 the National Pact was signed by three of the four rebel factions, but 'the Tuaregs continued to resist central authority until 1996 when Konaré (democratically elected in 1992) brought the rebellion to a close through negotiations and promises of administrative reform' (Smith 2001:75). On 27 March 1996 the peace process was celebrated by the burning of 3,000 firearms which was attended by both government officials and rebel leaders and marked the end of the six-year conflict (University of Maryland 2007). Horizontal inequalities between the Northern and Southern populations were the root cause of the Malian conflict. As a result of a concerted effort to resolve the horizontal inequalities, governmental stability has increased and violence has ceased between the two groups.

The Tamanrasset Accords, while imprecise and unpopular, were the basis for the National Pact, which eventually led to peace. The National Pact had many similarities with the Tamanrasset Accords. However, its construction was more holistic, reasonable and confronted the roots of the Malian conflict. The National Pact, signed in April 1992, included integration of Tuareg combatants into the Malian armed forces, demilitarization of the north, economic integration of northern populations and a more detailed administrative structure for the three northern regions' (Seely 2001:507). The National Pact, unlike other agreements, went to great lengths to explicitly recognise the economic marginalisation of the northern populations. Moreover, in a speech on 9 November 1991 Col. Toumani Touré recognised that 'all Malians, including people in the North, should have the same rights and should be treated equally' (Storholt 2001:341). Furthermore, 'He admitted that the Malian government had done wrong in the past and officially apologized to the people of the north' (Storholt 2001:342). The recognition of economic and political neglect helped foster an environment of cooperation, while demonstrating governmental willingness to first admit to and then rectify past actions. The peace process was aided in part because 


\section{David McCoy}

the new government was willing to engage all sectors of society in order to create a more democratic and progressive society. The willingness of the government to admit wrongdoing and the inclusion of the northerners in the military, governmental, and economic sectors of society along with a proactive reform agenda of decentralisation paved the way for the northerners and the government to reach a mutually beneficial agreement.

The Tuareg's secessionist-centred goal was rectified by the transitional and the permanent government's policy of decentralisation. The policy of decentralisation was originally confined to the north; but 'shortly after taking office in the newly democratic Malian Republic...President Alpha Oumar Konaré decided to implement a nation-wide policy of decentralization' (Seely 2001:495). This policy allocated administrative and fiscal control over health, education and some infrastructure to the local communes (Seely 2001). The decentralisation of the country, especially the north, had a threepart effect. The government was able to consolidate power, gain legitimacy in the eyes of the public and the dissidents, and mitigate the threat from the north. The promises of economic and political inclusion, as well as decentralised rule was strengthened by the government's political will to follow through with the agreed framework.

The last major incident which helped to create a workable and ultimately successful peace plan was the development by both sides of what I. William Zartman (1995:18) called 'hurting stalemate'. He writes, 'Negotiations take place when both parties lose faith in their chances of winning and see an opportunity for cutting losses and achieving satisfaction through accommodation.'In Mali, both parties to the conflict recognised they had more to gain through dialogue than through violence. In fact, 'what characterized the peace process in Mali was first the will to find a peaceful solution, and second, a strategy for managing the conflict' (Storholt 2001:334). The conflict in Mali came to a resolution while the new government was attempting to regain control and legitimacy throughout the country. As a result, they managed to end the six-year conflict while developing a democracy that has 'found firm support in recent economic growth, social structures conducive to equality, a unique political culture, a favorable international environment 
and effective political leadership' (Smith 2001:73). Mali's successful peace process can be attributed to a responsive government admitting past neglect, a peace accord that addressed the root causes of conflict i.e. economic and political horizontal inequalities between the north and the south, and the advent of a 'decentralized administration that gave real authority to previously voiceless local governments' (Pringle 2006:33).

\section{Rwanda}

In the summer of 1994, Rwanda, a 'quite scenic country in Central Africa, whose very nature exudes serenity became the venue of the cruellest butchery ranking among the biggest tragedies of the 20 ${ }^{\text {th }}$ century' (Dulian 2004:40). The Rwandan genocide of over 800,000 Tutsis came as the result of historic and modern inequalities between the Hutu majority and the Tutsi minority. The deep animosities that have plagued Rwandan politics are rooted in the historical management of colonialism. Relations between Hutu and Tutsi have always been one of status. However, historically, the lines between the two distinctions were fluid and changeable and the two groups had much in common. The Hutu and Tutsi 'developed a single and highly sophisticated language, Kinyarwanda, crafted a common set of religious and philosophical beliefs, and created a culture which valued song, dance, poetry, and rhetoric' (Human Rights Watch 1999:1). In pre-colonial Rwanda, power was attained by the acquisition of cattle and because the Tutsi were primarily pastoralists, they became the elite class within Rwandan society. This was an informal process resulting in a system by which both groups could attain power, and where class mobility and intermarriage existed (Shah 2003:2). Even though the 'minority Tutsi dominated over the Hutu... it was Belgium, which after taking control from Germany following World War I, institutionalized Tutsi dominance and solidified these divisions through the issuance of ethnic identity cards' (Kuperman 1996:223). The institutionalisation of Hutu and Tutsi as distinct people introduced for the first time the idea of race. Moreover, the colonialists developed the so-called Hamitic hypothesis which held that the Tutsi and everything humanly superior in Central Africa came from ancient Egypt or Abyssinia. Because of the solidification of identity as 


\section{David McCoy}

the main determinant of access and power and because the Tutsis were seen as more European, they became the privileged minority in a nation that was becoming more stratified. What evolved in Rwanda was the development of two distinct identities. The Hutu was an identity of subjugation and the Tutsi was an identity of power. While membership as a Tutsi did not necessarily result in power, it did grant them exemption from the most cruel and degrading treatment reserved for the Hutu population. By the end of the colonial era, Rwanda was a nation defined by identity. The Hutu saw the Tutsis as oppressors and foreigners, a distinction that would play a huge role in post-colonial Rwanda.

Between independence and the 1994 genocide, Rwanda had two successive Hutu republics. The opportunity to eradicate the system of rigid identity instituted under colonialism was at hand, however, 'the 1959 revolution turned the world colonialism created upside down; but it did not change... instead of challenging the identities [the new government]...embraced them' (Mamdani 2002:500). The sixty years of colonialism and Tutsi rule 'inflated Tutsi egos inordinately and crushed Hutu feelings, which coalesced into an aggressively resentful inferiority complex' (Magnarella 2003:25). During the first republic under Kayibanda, many Tutsi fled to surrounding nations, including Uganda. Those that remained in Rwanda faced widespread oppression and a violence that was not only accepted, but rewarded. This violence was realised during the first republic, where intermittent massacres of Rwandan Tutsi occurred in 1963, 1967 and 1973 (Kuperman 1996:223). The development of the second republic was the result of a 1973 coup orchestrated by General Juvenal Habyarimana. Under the second republic 'Habyarimana officially redefined Tutsi from a race into an ethnic group... with political rights and with proportional representation in parliament, in embassies, in the cabinet, even in the army' (Mamdani 2002:500). The second republic's attempt to rectify and put the past to rest was tempered by opposition Hutus residing outside of northern Rwanda. The new regime 'went to great lengths to integrate Tutsi elements into society and publicly stressed the need for national reconciliation' (Fujii 2004:101). However, the Hutu were divided into two groups: the Parmehutu, who wielded power 
during the first republic, and the minority Hutu, who occupied the north. With General Habyarimana's successful coup the economic, political, and military power in Rwanda shifted to northern Hutus, which engendered aversion from the Hutu as well as Tutsi (Kuperman 2000:95). The most contentious issue, which brought about the 1990 civil war, was the issue of the Tutsi refugees residing in Uganda. 'Habyarimana adamantly refused to allow their (Tutsi refugees) return, insisting that Rwanda was already too crowded and had too little land, jobs and food for them' (Magnarella 2003:26). As a result of the problems with the Ugandan and the Rwandan governments' handling of refugees, 'an expatriate rebel force composed mainly of Uganda-based Tutsi refugees, the Rwandan Patriotic Army (RPA), invaded northern Rwanda' (Kuperman 2000:95). The civil war between the government and rebels lasted until 1993 when the Arusha Accords, a powersharing agreement between the Hutu government and the Tutsi refugees/ rebels, was signed in 1993.

The Arusha Accords were under-funded and operated on an unrealistic timetable that was unable to appease the more extremist factions within the Hutu power structure. The northern Hutu under Habyarimana controlled political patronage, and dominated the civil service, both key sources of power (Kuperman 1996:223-224). The entrenched political elite of the north 'viewed the accords as abject surrender to the Tutsi, who they feared would seize the spoils of rule and seek retribution' (Kuperman 2000:96). As President Habyarimana was taking steps to ensure the implementation of Arusha, his plane was shot down on 6 April 1994. This acted as the trigger for Hutu extremists focused on retaining control of Rwanda to enact a campaign of genocide against the Tutsi population (Human Rights Watch 1995). The sudden and mysterious death of the Rwandan president set in motion one hundred days of horror that decimated the Tutsi population and led to the overthrow of the second republic when the Rwandan Patriotic Front (RPF) ${ }^{3}$ took Kigali and instituted a unilateral ceasefire and a return to Tutsi rule.

3 Within the organisation of the rebel movement the Rwandan Patriotic Army (RPA) was the military arm of the Rwandan Patriotic Front (RPF). For an in-depth analysis of the history and evolution of the RPF refer to Reed 1996:479-501 and Kuperman 2004:61-84. 


\section{David McCoy}

The genocide in Rwanda was the result of deep and systemic horizontal inequalities within the political, economic and military sectors of society. The inequalities were suffered by both 'identities' and resulted in widespread violence against both Hutu and Tutsi. These inequalities and the thirst for power, coupled with systemic social and economic insecurity, bred extremism which resulted in one of the most efficient and most deadly violent outbreaks of the modern era. In post-genocide Rwanda, the transitional government and the elected Tutsi leadership took many steps to rectify the deep divide brought upon by the events that took place in the spring and summer of 1994.

With the end of the genocide and the 'victory' of the RPF, Rwanda was in the hands of the minority Tutsi who were the majority of the genocide victims and the traditional oppressors within Rwandan society. With the inception of a new government the opportunity to change the system of domination and inequality was again at hand. The new RPF government came to power with two core priorities, the fostering of national reconciliation and the reduction of poverty (Zorbas 2004:37). The ability of the new government to accomplish these two goals will be instrumental in developing a peaceful and stable Rwanda. In a relatively short period, the national unity government accomplished a great deal, including the fostering of stability, developing the foundations for rule-of-law, aiding in the emergence of democratic and civil society and overseeing the normalisation of the financial sector (Dulian 2004). While democratic structures must be developed and rule-of-law must reign supreme, the government must resolve the issues that created the outburst of violence in the first place, namely economic and political exclusion. The president's call for 'prioritization of poverty reduction in all government programs' (Zorbas 2004:37) is a step in the right direction. The reduction of poverty will not only create stability, it will aid in the reconciliation process by giving those affected by the genocide the means to begin life anew. The government has also abolished the identity cards that did so much to stratify the society, stressing the idea of being a Rwandan not a Hutu or a Tutsi. Taken at face value this is a positive development, but what is 
beginning to emerge is a victim/perpetrator mentality which is making the deconstruction of the Hutu/Tutsi identity extremely difficult. Additionally, 'despite the government's insistence that ethnic divisions are a thing of the past, there is nothing to indicate that local communities accept this policy as anything more than naïve political rhetoric' (Tiemessen 2004:65). It must be recognised that obtaining local support for this policy will only be gained in time and should be seen as a very important step to creating equality. The abolition of official identity and the government's recognition that poverty must be a priority are steps in the right direction. There are three issues, however, that must be addressed if Rwanda is to have a stable and peaceful future: reconciliation, property and governance.

Reconciliation is the cornerstone of the Rwandan government's strategy to heal from the genocide. Currently there are about 120,000 people in custody for genocide charges. The severity of the charges range from being a chief architect of the genocide to people charged with looting and vandalising (International Crisis Group 1999:6). The main perpetrators of the genocide are being tried at the International Criminal Tribunal for Rwanda (ICTR), but the government retains responsibility for trying the majority of the ordinary killers. Given the poor condition of the Rwandan legal system, its ability to perform these duties is highly questionable. The government lacks a functioning court system, it is suffering from huge delays in setting up trial mechanisms, and it lacks adequate detention facilities to house the 120,000 prisoners.

The process of reconciliation is structured on three parts: the ICTR, domestic trials, and Gacaca. The first two divisions of reconciliation focus on retributive justice (that of punishment), while the third operates under restorative justice (that of healing and trust building). The ability of the government to accommodate the large number of perpetrators and the ability of the Gacaca trials to succeed has been called into question mainly because of a lack of resources and of the length of time needed to perform these trials. The process of reconciliation is not having the effects that the post-genocide government would have liked. This is, in part, the result of the massive trauma inflicted upon the entire country; but there are also 


\section{David McCoy}

issues of victor's justice and the lack of equal punishment that continue to hinder national reconciliation.

The hard-handed control maintained by the RPF since its military victory in 1994 has led many to view the reconciliation process as victor's justice, creating greater animosities as the process of reconciliation is enacted. The perceived inequality of justice will destroy any legitimacy that the RPF would have attained and will contribute to the disunity of the country, making renewed conflict more likely.

The basis of the genocide hearings are in the Organic Law, which 'stipulates a jurisdiction over crimes committed between October 1990 and December 1994, including both the civil war and the genocide' (Tiemessen 2004:70). In that light, all illegal acts and perpetrators could be charged and punished; however, this has not happened. The new, primarily Tutsi government, has only been arresting and trying Hutus that committed crimes, without holding Tutsis accountable. During the years of Organic Law jurisdiction, the Tutsi were allegedly guilty of war crimes and crimes against humanity. The crimes included the forcible displacement of Hutu populations, moreover, according to Human Rights Watch, the RPF 'destroyed property, recruited child soldiers against their will, and displaced thousands in order to create free fire zones' (Human Rights Watch 1994:13). In order for any type of reconciliation to occur, whether based on retribution or restoration, both sides of a conflict must atone for their actions. Until the government of Rwanda holds soldiers and civilians guilty of crimes against the Hutu accountable, reconciliation will be impossible. Unless all proceedings are viewed as neutral and impartial, the reconciliation that is so sorely needed will never develop and Rwanda will be a country in the 'pursuit of justice without reconciliation' (Lemarchand 1998:13).

Property continues to be a contentious issue. Rwanda is the most densely populated country in Africa, and as a result issues of property are continuously creating issues of insecurity. In Rwanda, according to Human Rights Watch (1995), the 'atmosphere of insecurity was...heightened by frequent and bitter disputes over property'. With property in the post- 
genocide era such a contentious issue and because property issues were a major cause of animosity and insecurity (Fisiy 1998:24), the government must address this property issue. The main 'policy documents [regarding land] in circulation... aim to ensure food security and to increase offfarm income' (Van Hoyweghen 1999:367). The two-part focus will help to ensure that basic food needs are met while providing income-earning opportunities separate from agriculture. The need for land reform is evident to not only deal with the large population, but to help reintegrate refugees back into Rwandan society. The government continues to take strides to deal with land because it is 'widely believed that the problem [of development for peace and stability] can only be settled by major agrarian... reform' (Van Hoyweghen 1999:365).

Governance in Rwanda has for its entire modern history been that of inequality and repression, which led in large part to the events of 1994. In the post-genocide era the new government must develop an inclusive and representative government; but this has yet to take hold. The mainly Tutsi government is once again failing to address the structural inequalities that have led to so much bloodshed over the decades. Instead of taking a holistic approach to development; the current government 'is prioritizing economic and social rights while ignoring civil and political rights' (International Crisis Group 2002:2). In fact, 'police control over all forms of opposition, both within and outside the regime, has steadily increased [and] the press, associations and opposition parties have been silenced, destroyed, or co-opted' (International Crisis Group 2002:1). The lack of progress in governance is making violence an 'increasingly attractive option, which in turn fuels security pressures on the regime' (International Crisis Group 2002:2). However all is not lost; President Kagame has declared that all presidential and legislative elections will be carried out by direct universal suffrage and through secret ballot. Moreover, 'the Rwandan government has made efforts towards reconciliation including the reintegration of ex-Forces Armées Rwandaises Hutu soldiers into the army' (International Crisis Group 2002:7). It still remains to be seen whether the government will distance itself from the authoritarian tendencies that have defined 
RPF rule since the end of the genocide. ${ }^{4}$ Without a more equalised and representative governing structure, massive land reform, and a reconciliation process based on restorative justice, Rwanda will never be able to achieve stability and will once again fall victim to outbursts of violence as a way to rectify grievances that have come as a result of horizontal inequalities.

\section{Moving Forward: Lessons from Malian and Rwandan Experience}

The Rwandan and Malian experience can inform the way scholars and practitioners address post-conflict societies. These conflicts are very different and their levels of success are as dispersed as the trauma each society has faced, but while Mali can be viewed as a successful post-conflict society, Rwanda has a long road to travel. What makes these two conflicts alike is that they occurred as a result of horizontal inequalities and provide valuable insights as to the best approach in addressing the inequalities that have served as a catalyst for conflict.

\section{Peace Agreements}

The development of peace agreements is a necessary and inevitable part of the peace process. Accordingly, the Rwandan and the Malian peace process can offer some guidance when building a peace accord. First, the construction and enforcement of peace agreements are oftentimes not fluid or flexible enough when they create specific deadlines and obligations that are unattainable. Peace processes must have leeway built into them to ensure that they are as dynamic and flexible as the parties involved. Furthermore, the timetable that peace processes operate under must be realistic. Unfortunately, the international community too often places unrealistic time constraints on peace. Rebuilding a nation after war

4 As a way to demonstrate the authoritarian drift the International Crisis Group shows that 11 out of 12 prefects are affiliated with the RPF, 13 out of 15 ambassadors are RPF, 7 out of 9 security services are headed up by the RPF, the chief prosecutor of the Court of Cessation and head of the Constitutional Court are all members of the RPF, 8 out of 9 Rwandan banks are managed by RPF members, all institutes of higher education are run by RPF members, and 25 out of 29 leaders of the top state-run companies in Rwanda are RPF members. 
is a time-consuming endeavour and should not be rushed for financial or public relations concerns. The international community must allow for more lenient timetables when instituting peace in war-torn nations.

Secondly, peace accords must include as many actors as possible. In the case of Mali, the first attempt at peace was not sustainable, in part because some of the major parties were excluded from the negotiations. As a way of getting as many of these issues resolved as possible, the international community and domestic interests should ensure that all belligerents and interested parties have a voice.

Third, the effectiveness of a peace accord is dependent on it addressing the root causes of conflict. The Arusha Accords and the Tamanrasset Accords did not do an adequate job in dealing with the root causes of each conflict; as a result, their irrelevance became evident when more violence broke out. The National Pact in Mali did an outstanding job addressing the real grievances of the north and consequently was successful. The United Nations, African Union, United States, European Union, and other nations and groups that negotiate peace accords must strive to address the root causes of conflict or face inevitable failure.

Fourth, oftentimes in the peace process and the subsequent development agenda put forth, the focus is on the individual when it should be on the group. When measuring success the international community looks at the number of individuals helped or affected. Instead, the international community and national policy must focus on how groups of people are being affected. This refocusing in the peace and development agenda is necessary because paying attention only to individuals does not paint a complete picture. People and groups are motivated to conflict when they are deprived relatively, not absolutely. What is often lost in looking at development and post-conflict progress is which groups are making progress. Therefore, when nations have experienced conflict, those involved in reconstruction must focus their efforts on rectifying the root cause of the conflict as it relates to groups.

Fifth, the international community must show a sustained commitment to post-conflict societies. Oftentimes, nations emerging from conflict are 


\section{David McCoy}

so economically and politically disadvantaged that they lack the ability to enforce the stipulations of a peace agreement. This was the case in Rwanda where the Arusha Accords were unable to be adhered to because of the lack of resources and assistance from the international community. According to the United Nations Independent Inquiry into the Actions of the United Nations during the 1994 Genocide in Rwanda, 'the Rwandan people needed to be told that they had to rely on themselves during the interim period' (United Nations 1999:7). Too often the international community creates complicated and expensive peace structures and then leaves the war-torn country to administer them. Creating peace and development is very costly and takes a commitment by the international community to underwrite the financial burden of post-conflict reconstruction. The international community should develop an international peace fund that will help defer the cost of implementing peace agreements. The current mechanism is too ad hoc and inconsistent to be effective. Hence, advocating for the development of a more sustainable and consistent source of funding is necessary. The fund should be administered under the auspices of the UN, be controlled by the General Assembly and funded though national contributions. Given the reluctance of nations to increase their incurred cost to the UN, the fund would most likely be financed though voluntary donations. The necessity of consistent funding and assistance is evident, and in order for peace to develop in conflict zones there must be a reliable source of funding for peace endeavours worldwide.

Sixth, while developing the structures for peace, domestic and international actors must explicitly address issues of economic, social, political and refugee injustices. Actors must also build a framework for rectifying these issues in order for a nation to rebuild itself and not repeat the mistakes of the past. This is best exemplified in the Malian National Pact. The National Pact not only addressed the many issues that caused the conflict in the peace agreement, but the government and the northern rebels came to an agreement as to how to ensure that each group's grievances and concerns were addressed. This type of explicit recognition and plan of action should be utilised in all peace agreements and strategies for post-conflict states. 
While peace and stability are the ultimate goal, the international community and those interested in conflict resolution must understand that not all conflicts can be negotiated when they prefer to do it. When determining which conflicts the international community should spend its time and expertise on, they must look for what is commonly known as 'hurting stalemate'. A hurting stalemate occurs when all belligerents recognise that the continuation of violence will not be advantageous and that negotiating with the enemy is the best option available. This exact situation happened in Mali and as a result a viable and mutually beneficial peace was struck. If there is not a hurting stalemate, the possibility of the international community or any interested party ending a conflict will be very small. In order for peace to take hold, all parties must see it as beneficial. In the absence of a hurting stalemate the international community and those in the domestic realm must work towards creating a hurting stalemate through either diplomatic or coercive means. Instead of the UN or anyone intervening in conflicts and failing to establish peace, the UN must choose those conflicts that are ripe for resolution. With regard to belligerents that see conflict as beneficial, the role of the UN, neutral nations, and other interested parties to facilitate the development of a hurting stalemate is tremendously important.

Immediately after conflict and during the reconstruction phase, there must be a sustained effort to change the way people define themselves. This is being applied in Rwanda with abolition of ethnic identity cards. In nations where identity has played a crucial role in stability, as in Rwanda and Mali, nations must work to shift the focus away from sub-groups within the state. Instead, identity should be built around a national or regional consciousness, as is being tried in Rwanda. Moreover, nations should encourage the deconstruction of group identities by placing an emphasis on individual accountability through the development of viable economic and rule-of-law structures. In the case of Mali, the government was able to take a different approach to the problem of identity. Instead of working to integrate the northern populations into the larger Malian construct, they offered them a high amount of autonomy. This approach is possible and oftentimes easier to institute but can only work for groups that are already economically 


\section{David McCoy}

and geographically isolated. In the case of Rwanda, group autonomy is impossible given geographic constraints and the level of integration before violence occurred. In cases of a large degree of integration, the need to create a new national 'identity' is imperative, while in nations where there is a high level of isolation offering varying levels of autonomy may prove easier and more acceptable to the populations involved.

\section{Truth and reconciliation}

The need for a war-torn nation to develop formal mechanisms for truth, reconciliation and justice is widely touted as a necessary step to creating stability and peace. The development of truth and reconciliation commissions (TRCs) has been worked into peace accords, and instituted in the former Yugoslavia, Sierra Leone, South Africa, Japan, Germany, Rwanda and others. One of the main goals of these formal proceedings is to find the truth about what happened. Obviously, however, 'truth is constituted by multiple facts, each of which is vulnerable to distortion, denial, rationalization and refutation' (Fletcher \& Weinstein 2002:588) and this makes the development of a common history extremely difficult. The National Pact in Mali had TRC mechanisms written into it so as to provide a forum for recovery; however, formal processes were never undertaken because the Malian people deemed them unnecessary. The case of Rwanda offers a good example of both a well and a poorly constructed TRC. One action that the international community should make compulsory in developing TRCs is that they should focus on principles of restorative justice and not on retribution. Rwanda has set up Gacaca courts that focus on truth telling and forgiveness as a way for the country to heal. Processes like Gacaca should be the cornerstones of any healing process utilising forgiveness and informal processes instead of retribution and punishment. It should be noted that the Gacaca trial is primarily for those who have admitted wrongdoing and who are not charged with the most severe crimes. In cases of genocide and massive atrocities the ability of individuals to forgive the perpetrators should be promoted as far as possible. 
The UN in conjunction with the Rwandan government has established the International Criminal Tribunal for Rwanda (ICTR) for those who played a more integral part in the planning and implementation of the genocide. ${ }^{5}$ This is problematic for two reasons. First, the tribunal takes place in Arusha, Tanzania, where the proceedings and decisions are carried out hundreds of miles away. Secondly, because the system of punishment established under the ICTR does not allow for the death penalty, many of the most responsible parties are subject to more lenient sentences than their compatriots. ${ }^{6}$ While it can be argued that those who carried out the actual murders are just as culpable if not more, the perceived leniency afforded the organisers of the genocide as well as the location of the trials are creating resentment and disillusionment by both the Tutsi and the Hutu. In fact, one prisoner replied, 'Why is it that the tribunal gives them more lenient sentences than us, they are the ones who told us to kill on radio...how come we are paying the higher price?' (Tiemessen 2004:62) The international community should 'in the case of international trials...support the efficient and impartial administration of justice on home soil' (Fletcher \& Weinstein 2002:596). Instituting justice at home will provide the victims access to the proceedings and create a visible environment of justice throughout the country.

In cases where there are large numbers of people held captive, the international community and the domestic leadership must work to ensure that the proceedings and accommodations are consistent with international human rights standards. Otherwise, those instituting justice risk becoming the perpetrators of injustice. This has become the case in Rwanda where more than a hundred thousand people are being held in substandard conditions,

5 Please see Article 1-9 of the Statute of the International Criminal Tribunal for Rwanda for a full articulation of the ICTR jurisdiction, located at <http://69.94.11.53/ENGLISH/ basicdocs/statute/2007.pdf> (Accessed 25 May 2008)

6 Article 23.1 of the Statute of the International Criminal Tribunal for Rwanda states, the penalty imposed by the trial chamber shall be limited to imprisonment. Located at <http://69.94.11.53/ENGLISH/basicdocs/statute/2007.pdf> (Accessed 25 May 2008). It should be noted that those indicted and prosecuted nationally under the 1996 Organic Law are, depending on their level of involvement, subject to the death penalty. 


\section{David McCoy}

lack adequate nutritional support and are dying before they receive a fair hearing.

With large scale atrocities and tribunals come large numbers of prisoners. As a result, when developing and carrying out punishments, the international community and domestic parties should, like those of Rwanda, use restorative practices as a way to defer the costs of building large numbers of correctional facilities. Those convicted of crimes relating to the genocide are, by and large, being sent to 'work camps' to rebuild the nation that they helped destroy. The idea behind this approach is that those guilty of harming people can atone for their actions by helping to rebuild the communities they have harmed. This will, in turn, aid in the nation's recovery and demonstrate to the victims that the guilty are trying to make amends. International and domestic processes of restorative justice in punishment should be advocated for.

Lastly, in carrying out truth and reconciliation and criminal trials, there must be accountability of all sides in order to facilitate healing. In Rwanda the criminal proceedings are one-sided with the Hutu génocidaires receiving punishment for their crimes while the RPF, who were perpetrators of war crimes and crimes against humanity during the 1990-1993 civil war and in the wake of the genocide, have eluded punishment. If the truth that is established or the criminal proceedings are seen as victor's justice there will be no peace. Furthermore, this can quite possibly lead to more animosity, mistrust and conflict. Those involved in any TRC must approach the process of truth seeking and reconciliation on the side of impartiality and hold all people and groups accountable for their actions. Otherwise, they must risk facing the continuation of conflict.

As part of the reconciliation which is necessary for a society to heal after a traumatic event, one of the most important actions groups can perform is admitting wrongdoing. In the Malian case, the government explicitly admitted that the northern populations were harmed by government policy and that they were entitled to the same rights and privileges as any other Malian. This action constitutes a necessary starting point in any recovery, 
helping to build trust between oppressed and oppressor. In Rwanda, neither the Hutu nor the Tutsi have offered an apology for the harm they have suffered upon each other throughout the years. The Hutu must publicly show remorse for the genocide they orchestrated, and the Tutsi must admit to the atrocities that unfolded during the civil war of the 1990s as well as to the pain and alienation they caused during their years of domination. Moreover, there must be a rhetorical and actual commitment devoted to the prevention of such harm in the future. Without this necessary step, trust will not develop, and without trust there cannot be cooperation. Admission and atonement are vital when healing from conflict. It demonstrates that the wrongdoer is aware of his/her actions and is willing to make amends while altering these actions. Within the context of conflict, those who have instigated and carried out violent acts should in all cases publicly address their actions. Oftentimes this must be done by all parties involved because in many conflicts, especially in Africa, there is blood on everyone's hands.

\section{Access: citizenship, property and identity}

The issue of society membership and identity is a problem that must be addressed in order for stability to materialise. Citizenship in Rwanda and Mali was a major issue in post-conflict reconstruction. Citizenship was at the heart of both civil wars and as a result must be addressed. The issue of who is (as well as who is not) a citizen was also seen in South Africa, Côte d'Ivoire, the former Yugoslavia, and many other conflict zones around the world. The denial of full citizenship and the inability of all citizens to obtain equal access results in 'the central state becom[ing] an arena... with the more powerful...groups excluding and submerging the lesser ones and denying their people the benefits of citizenship' (Adejumobi 2001:162). Consequently, all nations must construct citizenship identities in a fair and equitable manner, without discrimination against race, ethnicity, religion, socioeconomic status, geographic location, and/or historical myth. Moreover, nations must abide by and enforce the 1951 United Nations Convention Relating to the Status of Refugees and the 1969 Organisation of African Unity Convention Governing the Specific Aspects of Refugee Problems in 


\section{David McCoy}

Africa and allow refugees to repatriate regardless of the economic, social, or political hardships that the nation may incur. In Rwanda for instance, if the Hutu government had created space for Tutsis to repatriate, then the civil war of the early 1990's may not have materialised and the genocide could have been avoided. The international community should also play a role in ensuring that citizenship is a right by enforcing the refugee conventions and providing support to nations with highly factionalised populations.

Along with citizenship rights, property rights remain a very contentious issue within post-conflict societies. This is demonstrated in both the Malian and the Rwandan cases. Nations must therefore strive to ensure that every group has an equal opportunity to access land. It is not necessary for every person to be granted land, but each person and group must have the ability to obtain property. There should be no arbitrary restrictions on land access. Moreover, every group within a nation must have access to the products of land, namely for food and economic security. Governments experiencing land grievances must, like that of Rwanda, reform the agrarian and land use policies and practices. If a nation experiences conflict as a result of land grievances, redistribution and equitable access to land must be explicitly written into the ensuing peace accord.

\section{Conclusion}

Within the international community there has been a marked improvement in the number of conflicts resolved worldwide. In no other place have the effects of the international community and third parties been felt as much as in Africa. During the last decade, a number of conflicts have come to a close in Africa and worldwide. In fact, in the last five years conflicts in the Democratic Republic of the Congo, Sudan, Sierra Leone, Liberia, and Côte d'Ivoire have come to a close. A new chapter in African history is upon us - one of reconstruction, not war. The many conflicts that have ravished the African continent can help inform domestic and international parties as to how best to rebuild shattered societies. Examining the past also helps those who are studying conflict management understand conflict and prevent 
future conflict. One of the most destructive and under-appreciated causes of violent conflict is that of horizontal inequalities. These inequalities have been among the causes of all of the aforementioned conflicts along with the two conflicts addressed in this paper. The Rwandan and the Malian conflicts can help practitioners develop a comprehensive strategy for nations ravished by horizontal inequalities. While this paper is far from comprehensive, it has offered policymakers and practitioners strategies to enable nations to rise from the ashes of conflict. The international community and those within the field of conflict management have the knowledge to mitigate the root causes of conflict. Theoretically, we as a community are well equipped; what is needed now is to translate the volumes of theory into an operational strategy. We must fill the gap between theory and practice. This gap must be bridged though a sustained long-term commitment of resources, both human and financial, in order to rectify the horizontal inequalities that are often at the root of so many conflicts. If action fails to materialise, the African continent will inevitably backtrack into the violence the international community has worked so hard to terminate.

\section{Sources}

Addison, Tony \& Murshed, S. Mansoob 2001. From Conflict to Reconstruction: Reviving the Social Contract. Discussion Paper No. 2001/48. Helsinki: UNU/WIDER.

Adejumobi, Said 2001. Citizenship, Rights, and the Problem of Conflicts and Civil Wars in Africa. Human Rights Quarterly 23.

Azarya, Victor 2003. Ethnicity and Conflict Management in Post Colonial Africa. Nationalism and Ethnic Politics 9 (3).

Ballentine, Karen \& Nitzschke, Heiko 2003. Beyond Greed and Grievance: Policy Lessons from Studies in the Political Economy of Armed Conflict. IPA Policy Report. New York: International Peace Academy.

Berry, John A. \& Berry, Carol Pott (eds) 1999. Genocide in Rwanda: A Collective Memory. Washington, D.C.: Howard University Press.

Brown, Mark Malloch 2003. Democratic Governance: Toward a Framework for Sustainable Peace. Global Governance 9.

Busumtwi-Sam, James 2002. Sustainable Peace and Development in Africa. Studies in Comparative International Development 37 (3).

Central Intelligence Agency 2006. CIA Fact book 2006. Available at: <http://www.cia.gov/ cia/publications/factbook/geos/ml.html > Accessed 17 Feb 2007. 
Cohen, A. 1974. Two-Dimensional Man: An Essay on the Anthropology of Power and Symbolism in Complex Society. Berkeley, CA: University of California Press.

Collier, Paul \& Hoeffler, Anke 2001. Greed or Grievance in Civil War. Policy Research Paper No. 2355. Washington D.C.: The World Bank.

Dulian, Aleksei 2004. Rwandan Genocide. International Affairs: A Russian Journal of World Politics, Diplomacy and International Relations 50 (4).

Economist 1990. Tuareg Return. Vol. 317 Issue 7676 (October 13, 1990).

Fisiy, Cyprian F. 1998. Of Journeys and Border Crossings: Return of Refugees, Identity, and Reconstruction in Rwanda. African Studies Review 41 (1).

Fletcher, Laurel E. \& Weinstein, Harvey M. 2002. Violence and Social Repair: Rethinking the Contribution of Justice to Reconciliation. Human Rights Quarterly 24.

Fujii, L.A. 2004. Transforming the Moral Landscape: The Diffusion of a Genocidal Norm in Rwanda. Journal of Genocide Research 6 (1).

Gurr, Ted Robert 1970. Why Men Rebel. Princeton, NJ: Princeton University Press.

Homer-Dixon, Thomas 1999. Environment, Scarcity, and Violence. Princeton: Princeton University Press.

Human Rights Watch 1994. Arming Rwanda: The Arms Trade and Human Rights Abuses in the Rwandan War. Available at: <http://hrw.org/doc/?t=africa_pub\&c=rwanda $>$ Accessed 18 May 2008.

Human Rights Watch 1995. Rwanda: Human Rights Development. Available at: <http:// www.hrw.org/reports/1995/WR95/AFRICA-08.htm> Accessed 5 Dec 2006.

Human Rights Watch 1999. Leave none to tell the story: Genocide in Rwanda. Available at: <http://www.hrw.org/reports/1999/rwanda/Geno1-3-09.htm> Accessed 27 Oct 2005.

Humphreys, Macartan \& Ag Mohamed, Habaye 2007. Senegal and Mali: A Comparative Study of Rebellions in West Africa. Available at: <http://www.columbia.edu/ mh2245/ papers1> Accessed 23 Feb 2007.

International Crisis Group 2002. End of Transition in Rwanda: A Necessary Political Liberalization. ICG Africa Report No53 (13 November 2002).

Kaplan, Robert 1994. The Coming Anarchy. Atlantic Monthly Feb 1994.

Kuperman, Alan J. 1996. The Other Lesson of Rwanda: Mediators sometimes do more damage than good. SAIS Review 16 (1).

Kuperman, Alan J. 2000. Rwanda in Retrospect. Foreign Affairs Jan/Feb 2000.

Kuperman, Alan J. 2004. Provoking Genocide: A Revised History of the Rwandan Patriotic Front. Journal of Genocide Research 6 (1), 61-84.

Lemarchand, René 1998. Genocide in the Great Lakes: Which Genocide? Whose Genocide? African Studies Review 41 (1).

Lode, Kåre 1997. Civil Society Takes Responsibility - Popular Involvement in the Peace Process in Mali. International Peace Research Institute, 1/97. Available at: $<$ http://www. prio.no/page/Publication_details/Staff_alpha_ALL/9429/38063.html $>$ Accessed 26 Feb 2007. 
Magnarella, P. 2003. Explaining Rwanda's 1994 genocide: A review of Mahmood Mamdani, When Victims Become Killers: Colonialism, Nativism, and the Genocide in Rwanda. (Princeton, NJ: Princeton University Press, 2001) 364 pp. and John A. Berry and Carol Pott Berry (eds.), Genocide in Rwanda: A Collective Memory. (Washington, DC: Howard University Press, 1999), 201 pp.: Human Rights \& Human Welfare, 2, no.1 (Winter 2003): 25-34. Available at: <http://www.du.edu/gsis/hrhw/volumes/2002/2-1/ magnarella2-1.pdf $>$ Accessed 11 Jul 2005.

Mamdani, Mahmood 2002. African States, Citizenship and War: A Case-Study. African Affairs 78 (3).

Østby, Gudrum 2005. Horizontal Inequalities and Civil Conflict. $46^{\text {th }}$ Annual Convention of the International Studies Association 23 (February 2005).

Østby, Gudrum 2006. Horizontal Inequalities, Political Environment and Civil Conflict: Evidence from 55 Developing Countries. CRISE Working Paper No. 28. Oxford: CRISE.

Ottaway, Marina 2003. Promoting Democracy after Conflict: The Difficult Choices. International Studies Perspectives 4.

Pringle, Robert 2006. Mali's Unlikely Democracy. Wilson Quarterly 30 (2).

Reed, Wm. Cyrus 1996. Exile, Reform, and the Rise of the Rwandan Patriotic Front. The Journal of Modern African Studies 34 (3).

Sambanis, Nicholas 2004. Poverty and the Organization of Political Violence. Brookings Trade Forum (2004).

Seely, Jennifer C. 2001. A Political Analysis of Decentralization: Coopting the Tuareg Threat in Mali. Journal of African Studies 39 (3).

Shah, A. 2003. Conflicts in Africa: Rwanda. Global Issues Jun 2003. Available at: <http:// www.globalissues.org/Geopolitics/Africa/Rwanda.asp> Accessed 11 Feb 2005.

Smith, Zeric Kay 2001. Mali's Decade of Democracy. Journal of Democracy 12 (3).

Stewart, Frances 2000. Crisis Prevention: Tackling Horizontal Inequalities. Oxford Development Studies 28, no. 3 (2000).

Stewart, Frances 2002. Horizontal Inequalities: A Neglected Dimension of Development. Working Paper Number 81. Oxford: QEH Working Paper Series, 2002.

Stewart, Frances 2006. Policies toward Horizontal Inequalities in Post-Conflict Reconstruction. Research Paper No. 2006/149. Helsinki: UNU/WIDER.

Storholt, Kristine Hauge 2001. Lessons Learned from the 1990-1997 Peace Process in the North of Mali. International Negotiation 6.

Tiemessen, Alana Erin 2004. After Arusha: Gacaca Justice in Post-Genocide Rwanda. African Studies Quarterly 8 (1).

Tirtosudarmo, Riwanto 2006. Population, Ethnicity, and Violent Conflict. Population Review Publications 45 (1).

United Nations 1999. Report of the Independent Inquiry into the Actions of the United Nations during the 1994 Genocide in Rwanda. United Nations Security Council, S/1999/1257 (16 Dec 1999). 


\section{David McCoy}

United Nations Development Programme 2007. Human Development Index 2006. Available at: <http://hdr.undp.org/hdr2006/statistics/> Accessed 17 Feb 2007.

University of Maryland 2007. Tuareg Chronology. Center for International Development and Conflict Management. Available at: <http://www.cidcm.umd.edu/inscr/mar/data/ malituarchro.htm> Accessed 26 Jan 2007.

Van Hoyweghen, Saski 1999. The Urgency of Land and Agrarian Reform in Rwanda. African Affairs 98 (392).

Volkan, Vamik 1997. Bloodlines: From Ethnic Pride to Ethnic Terrorism. Boulder, CO: Westview Press.

Zartman, I. William 1995. Elusive Peace: Negotiating an End to Civil Wars. Washington D.C.: Brookings Institute.

Zorbas, Eugenia 2004. Reconciliation in Post-Genocide Rwanda. African Journal of Legal Studies 1 (1). 